\title{
The court of women in early Palaiologan Byzantium (ca.1260-1350)
}

\section{Frouke Schrijver}

Independent researcher, Amsterdam

froukeschrijver@hotmail.com

This article serves as a contribution to the discussion of gender segregation at the imperial court of Byzantium. Evidence from the Palaiologan period shows that many of the elements of a women's court, as it was known from earlier centuries, were still present in the last centuries of the empire.

Key words: imperial women; gender segregation; women's court; Palaiologan Byzantium

In their groundbreaking article on the social make-up of the Middle Byzantine court, Alexander Kazhdan and Michael McCormick state that the court was, among other things, characterized by gender segregation: imperial women led their life largely separate from that of their husbands, in the court of women. The empress was the pinnacle of this separate social and institutional group. It was she who received the wives of court officials in audience during the Easter liturgy. ${ }^{1}$ At the coronation or marriage of an empress, imperial women participated in ceremonial in hierarchically arranged groups, parallel to the male court. ${ }^{2}$ In a similar manner, imperial banquets were held separately on certain occasions, one for men and one for women, as the visit of princess Olga of Kiev in the tenth century demonstrates. ${ }^{3}$ Kazhdan and McCormick suggest that this situation changed under the Komnenoi (eleventh to twelfth centuries), when imperial

1 A. Kazhdan and M. McCormick, 'The social world of the Byzantine court,' in H. Maguire (ed), Byzantine Court Culture from 829 to 1204 (Washington D.C. 1997) 167-97, 182-84. Much has been written about empresses or women in Early Byzantium, less so about the court of women. See for example L. James, Empresses and Power in Early Byzantium (London and New York 2001) 50-59 ; A. McClanan, Representations of Early Byzantine Empresses. Image and Empire (New York and Houndmills 2002), 130135.

2 For the protocol of these ceremonies see books 40 and 41 of Constantine VII Porphyrogennetos, Constantini Porphyrogeniti imperatoris de cerimoniis aulae Byzantinae libri duo, ed. J. J. Reiske, 2 vols. (Bonn 1829) I, 202.5-216.3; trans. A. Moffatt and M. Tall (Canberra 2012) I. 202-16. For comments on this passage and the independent role of the empress in De Ceremoniis see A. Moffatt, 'Variations in Byzantine imperial ceremonial: the De Ceremoniis of Constantine Porphyrogennetos,' Byzantinische Forschungen 24 (1997) 219-227, 224-225.

3 De cerimoniiis, 2.15 (I, 595.20-598.12).

(C) Centre for Byzantine, Ottoman and Modern Greek Studies, University of Birmingham, 2018

DOI: $10.1017 /$ byz.2018.6 
women seem to have participated more often in palace banquets that were also attended by men and followed the court outside the capital. This apparent relaxation of gender segregation caused, according to Kahzdan and McCormick, 'yet another significant social shift' in court society and may have been inspired by a western European lifestyle. ${ }^{4}$ The presumed lessening of gender segregation is exemplified by two passages in Niketas Choniates' History, which state that imperial women were present at a palace banquet, and that a female relative of the emperor was in a camp with other members of the court, and by a passage in Zonaras, who claims that the empress Eirene accompanied her husband Alexios I (1081-1118) on campaign. ${ }^{5}$ The latter is also attested by Anna Komnene. ${ }^{6}$

Linda Garland corroborates Kazhdan and McCormick's suggestion in her article 'Life and ideology of Byzantine women' and in a chapter 'Imperial women and entertainment,' of Byzantine Women, although she states that also under the Komnenoi specific elements of the women's court were preserved: despite some shared activities of imperial males and females, women still had a private space in the palace, some of their own ceremonies (receiving the wives of title holders in audience) and their own social sphere expressed in, for example, the existence of special servants for women. ${ }^{7}$

Little has been said about gender segregation at the imperial court in post-Komnenian Byzantium. While we may assume that a women's court was preserved in some form during the last centuries of the empire, the extent to which women were segregated in the imperial household remains obscure. By investigating the imperial household in late Byzantium, specifically in the early Palaiologan period (ca.1260-1350), this article examines how late-Byzantine imperial women were separated from the male court in terms of private space, ceremonial and social spheres.

4 Kazhdan and McCormick, 'The social world,' 185. Although it lies beyond the scope of my article to do so, Kazhdan and McCormick's bold statement on the difference between the Early and Middle Byzantine court of women deserves further attention. This subject is explored in R. Macrides, 'Women in the Late Byzantine court', in E. Kountoura Galanaki and E. Mitsiou (eds.), Female Monasticism in the Late Byzantine Period (1204-1453) (Athens 2018).

5 Imperial women at a banquet: Niketas Choniates, Nicetae Choniatae historia, ed. J.- L. van Dieten (Berlin 1975) 441.23-27 and imperial women on expeditions: 104.49-52; John Zonaras, Ioannis Zonarae epitomae historiarum libri xviii, ed. T. Büttner-Wobst, Corpus Scriptorum Historiae Byzantinae (Bonn 1897) III,18.26.9, 373.12-15. See Kazhdan and McCormick, 'The social world,' 184.

6 Anna Komnene, Annae Comnenae Alexias, eds. A. Kambylis and D. R. Reinsch (Berlin and New York 2001) IX.5.3.42-45.; XIV4.1.49-51; XV.1.6.77-XV.2.2.5 and in particular the passage in which Anna Komnene expands on the two reasons why Eirene went on campaign with the emperor (the empress acted as his personal caretaker - he suffered from gout - and also had to watch out for conspirators against him): XII.3.2.78-XII.3.10.86. This lengthy passage suggests that Eirene's presence needed explanation.

7 L. Garland, 'The life and ideology of Byzantine women: a further note on conventions of behaviour and social reality as reflected in eleventh- and twelfth-century historical sources,' Byzantion 58 (1988) 361-93; L. Garland, 'Imperial women and entertainment at the Middle Byzantine court,' in L. Garland (ed), Byzantine Women AD 800-1200: Varieties of Experience (London 2006) 177-191, 177-178. 


\section{A private space: the imperial gynaikonitis}

Royal women in late medieval societies were commonly provided with separate apartments in which they could hold court. ${ }^{8}$ Although the imperial women of Byzantium formed no exception, references to the actual physical gynaikonitis, 'women's quarters', of the imperial palace are few. ${ }^{9}$ Linda Garland has shown how some sources confirm the existence of women's quarters in the Middle Byzantine period and also later under the Komnenoi. ${ }^{10}$ Anna Komnene implies in the Alexiad that the twelfth-century women's quarters in the palace were nothing more than private apartments, divided by a curtain from a space where emperor Alexios received guests: 'a curtain divided the women's apartments from the room where the two emperors sat...'. ${ }^{11}$ From this we may infer that the twelfth-century imperial women were provided with a separate space in the imperial palace, yet that these women's quarters cannot have been very secluded. ${ }^{12}$

It seems likely that there was still a physical women's quarter in the palace under the Palaiologoi. From the 1260s the preferred imperial residence in Constantinople was the Blachernai palace, a complex of buildings located in the north-west corner of the city. In the absence of material remains, only textual sources can give information about the interior of the imperial residence. In the early fourteenth-century Lexicon Vindobonense of Andreas Lopadiotes, we find the lemma gynaikonitis explained as 'the gathering of women. The great imperial [gynaikonitis]. ${ }^{13}$ After this short explanation the lexicon offers an additional example of the use of the word gynaikonitis, which is taken from Basil of Caesarea's Hexaemeron and concerns astronomers standing outside the gynaikonitis, while something takes place inside. ${ }^{14}$ This means that according to the fourteenth-century lexicon, the gynaikonitis should be seen as the gathering of the

8 This was the case for medieval royal women in western Europe from at least the thirteenth century, see S. Rees Jones, 'Public and private space and gender in medieval Europe,' in J. Bennett and R. Karras (eds), The Oxford Handbook of Women and Gender in Medieval Europe (Oxford 2013) 246-61.

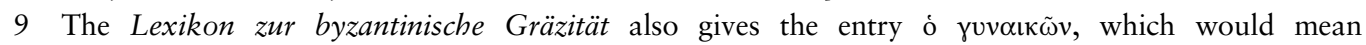
'Frauengemach', 'women's chamber', see E. Trapp (ed), Lexikon zur byzantinischen Gräzität: besonders des 9.-12. Jahrbunderts (Vienna 1996-2011) I, 333.

10 Garland, 'Life and ideology,' 382 and note 91.

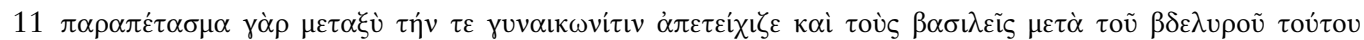

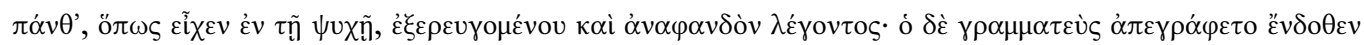

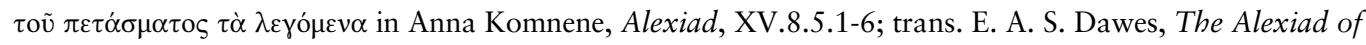
the Princess Anna Comnena (London 1928) 413. On curtains see M. G. Parani, 'Mediating presence: curtains in Middle and Late Byzantine imperial ceremonial and portraiture', Byzantine and Modern Greek Studies 42.1 (2018) 1-25.

12 However, Garland's conclusion, based on this passage in the Alexiad, that the gynaikonitis must have been centrally situated in the palace, requires more evidence, see Garland, 'Life and ideology,' 382.

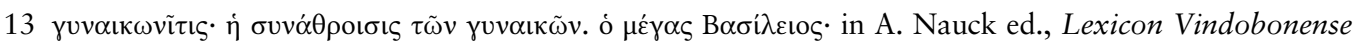
(St Petersburg and Leipzig 1867, repr. Hildesheim 1965), s.v. gamma, 20.1-3.

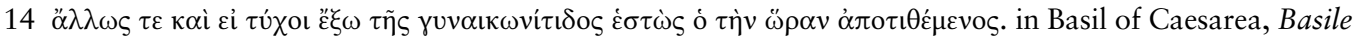
de Césarée. Homélies sur l’hexaéméron, ed. S. Giet, Sources chrétiennes 26 bis (Paris 1968) 6, 5.44). I am grateful to Paul Magdalino for identifying the passage. 
imperial women and their attendants, but the term also intimates a spatial element. ${ }^{15}$ Apart from this, there are no descriptions of the physical space of the imperial gynaikonitis by Palaiologan authors (was it still an area closed off by a curtain?), although the existence of women's apartments is implied in certain passages. For example, Nikephoros Gregoras says that the court official Alexios Apokaukos rushed to the palace in Constantinople during the second civil war (1341-1347) and decided not to appear before the empress Anna of Savoy, but rather 'went around the women's quarter'

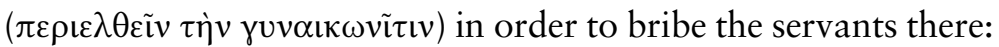

He thought upon his return, before visiting the empress with ashamed eyes, to go around the women's quarter with an abundance of money, [the women's quarter] which was powerful at that time, and also the entire body of servants, which filled the imperial residence. Having done this quickly and having proclaimed through them that he also would bring the empress the most beautiful and valuable treasures, he restored his former good repute. ${ }^{16}$

In this episode the gynaikonitis was accessible to a high member of the court like Apokaukos - he could 'go around', but it was also a group of people around the empress which formed her women's household.

The emperor-historian John Kantakouzenos (1347-1354) also discusses the empress Anna's gynaikonitis, indicating that this was both a space and a group of women confidants:

Sometimes, when she [Anna of Savoy] was alone in the women's quarters, she would say: 'It appears to me that I have been much deceived, having been

15 There are other meanings of the word gynaikonitis too, which are less relevant for descriptions of the imperial gynaikonitis. Kantakouzenos uses the term gynaikonitis for his own aristocratic women's household, when he states that he left his wife and her gynaikonitis at home, because it is too much trouble to take them with him. Here, the gynaikonitis must have meant the social group of female members of a household, distinct from the male household, and probably consisting of the people surrounding the lady of the house - her daughters perhaps, and her servants. See John Kantakouzenos, Ioannis Cantacuzeni eximperatoris historiarum libri iv, ed. L. Schopen, 3 vols. (Bonn 1828-1832) I, 24.24-25. Sometimes, another, more negative, sexual connotation of the word gynaikonitis is implied. In Gregoras' history we find a negative portrait of patriarch Niphon, who took up his office in 1310, and who was not only uneducated, ambitious, greedy and gluttonous, but also spent some of his time in the gynaikonitis, according to Nikephoros Gregoras, Nicephori Gregorae historiae Byzantinae, eds. I. Bekker and L. Schopen, 3 vols. (Bonn 1829-1855) I, 260.10. Likewise, the fourteenth century monk Joseph Kalothetos, in his fourth speech against Akindynos and Barlaam, uses the word in a metaphor, to explain that it is women, the gynaikonitis

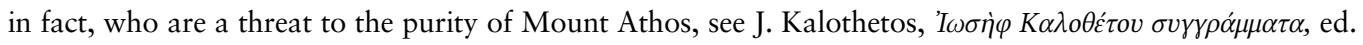

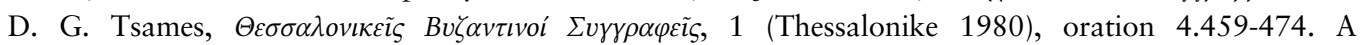
gynaikonitis in the sense of 'women for pleasure' can also be found in Pachymeres' history. See George Pachymeres, Georges Pachymeres. Relations historiques, ed. A. Failler, 5 vols., (Paris 1999-2006) II, 563.22. See also A. Failler, 'La tradition manuscrite de l'Histoire de Georges Pachymere (Livres I-IV),' Revue des études byzantines 37 (1979) 123-220, 143.

16 Gregoras, History, II, 711.5-12. 
persuaded [to believe] certain things about Kantakouzenos that are not [true].' For when she examined all he did in the time of the war, she found nothing by which she might be persuaded [to believe] that he plotted against her children. She overlooked, however, the evidence for these things which was most clear none of her words had anything sound to offer - by which she did not only harm herself, but also some affairs of the Romans. When the women asked what sort of remedy might be contrived for the evil things, now that he had already become emperor, the empress said, 'that is easy, for Kantakouzenos, when the emperor [Andronikos III] was still alive, had the power of an emperor, even though he was not dressed in imperial attire. Is it surprising that he does the same things as he did when he was wearing private clothing, now he wears imperial dress? Regarding his benevolence towards me and my son the emperor, when the war had not yet started, we agreed for his daughter Helena and my son the emperor to get married. If this happens now, the war will easily be dissolved, and affairs will be controlled by him, just like before. If not, there will be nothing to prevent the destruction of the rule of the Romans itself.' These women approved of the things said and deliberated how true and useful they would be. To them, they did not appear profitable. But the next day the things discussed were revealed to the parakoimomenos Apokaukos... ${ }^{17}$

This discussion between the empress and her ladies, at which the author was not present, gives in passing an insight into the whereabouts of the empress in the palace. We learn that in the mid-1340s the empress Anna of Savoy would sometimes withdraw into her gynaikonitis (an enclosed space in the palace?) and would discuss the movements of her adversary Kantakouzenos with her ladies. Moreover, the passage reveals that - yet again - the parakoimomenos Apokaukos had ready access to information discussed in the gynaikonitis, which confirms that this women's quarter was both relatively accessible and that its members freely interacted with male courtiers. This supports Lynda Garland's claim about twelfth-century Byzantium that imperial women were not secluded in their apartments. ${ }^{18}$

It appears that the empress was surrounded in her gynaikonitis by women whose opinion she respected which offered them a position of relative power. Although little is known about these women, we may assume that several of them were of high birth and were the empress' confidants from former times, when she was still an infant. The foreign origin of empresses like Anna, whose gynaikonitis features most prominently in the sources, might have played a role in creating a close-knit, separate group of female confidants. Usually, imperial brides from abroad arrived with a train of female attendants, many of whom stayed on to serve at the imperial court. ${ }^{19}$ Indeed, the aristocratic lady

17 Kantakouzenos, History, II, 202.19-203.20.

18 Garland, 'Imperial women and entertainment,' 179-180.

19 É. Malamut, 'L'impératrice byzantine et la cour (XIIIe-XVe siècle),' Recueil des travaux de l'Institut d'études byzantines 50 (2013) 645-61, 656-57. 
Isabelle de la Rochette, known as Zampea, was a lady-in-waiting of empress Anna and had come with her from her native region of Savoy. ${ }^{20}$ Kantakouzenos offers one report which suggests that Zampea remained in the imperial palace after the wedding of Anna with Andronikos III:

When the wedding celebrations were over, most of the men and women who had come with the empress from Savoy returned home. A few of them remained with her, however, and among them was a certain Zampea, one of the women, with her sons. She surpassed the other women in intelligence and based on her upbringing and other faculties it suited her to dwell in the imperial palace. $^{21}$

We know that Zampea was still present in Constantinople twenty years later, because Kantakouzenos refers to her again in his narrative of the second civil war. ${ }^{22}$ She may have been one of the trusted women with whom the empress discussed politics in her gynaikonitis.

A passage in Nikephoros Gregoras' History corroborates the power of the gynaikonitis of the empress Anna. Gregoras claims that in the 1340s, during the second civil war and the dispute about the doctrine of Gregory Palamas, the influential Constantinopolitan supporters of Palamas noticed the strengthening of the position of John Kantakouzenos against the empress and the patriarch and attempted to make an alliance with the empress. $^{23}$ The Palamite monks offered their support to the empress 'with the help of the archontes who were associated with her and the mass of people which filled the imperial gynaikonitis. ${ }^{24}$

In all cases, the authors want us to believe that the empress Anna's governance heavily relied on the opinion of the people who surrounded her, especially those of the gynaikonitis, and that the empress could be influenced politically through her servants. And, although this may well have been an attempt to discredit the government of a female regent, these references to Anna's women's quarters should also be interpreted as a social reality and as evidence of the sometimes hidden power of imperial women. Despite elements of negative portrayal, it becomes clear that the empress had private quarters where she was served by her personal attendants, could discuss political issues and could exercise power.

20 Zampea has been identified with Isabella de la Rochette. See T. S. Miller, The History of John Cantacuzenus (Book IV) (PhD dissertation, The Catholic University of America 1975) 313. Also, T. Teoteoi, 'La conception de Jean Cantacuzène sur l'état byzantin, vue principalement à la lumière de son Histoire,' Revue des études sud-est européennes 13.2 (1975) 167-185, 171.

21 Kantakouzenos, History, I, 205.2-8.

22 Kantakouzenos then spells her name as 'Zampaia': Kantakouzenos, History, III, 54.19.

23 For a discussion of Gregoras' statement that the Palamite supporters changed sides when Kantakouzenos appeared victorious, see J.-L. van Dieten, Nikephoros Gregoras. Rhomäische Geschichte, 5 vols. (Stuttgart 1979) V, 376 note 473.

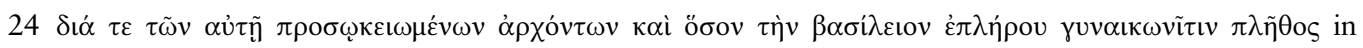
Gregoras, History, II, 785.14-15. 


\section{Social and ceremonial segregation}

In 1346 Eirene was crowned empress in Adrianople by her emperor-husband John Kantakouzenos. ${ }^{25}$ The following year she went to Constantinople and moved into the palace, after having been crowned again in the Blachernai church. Gregoras describes how the imperial men and women left the church together on horseback and then celebrated a joint dinner in the palace:

When the ceremony had ended, around the tenth hour [ca. 4 pm] of the twenty-first of May, they mounted horses, dressed in imperial attire, and made their way to the palace. There they made the usual display from a high platform and then they came down and, a meal having been prepared, they sat on the five thrones again. ${ }^{26}$

The five thrones at the dinner table were intended for the empress Anna, her son John, the emperor John Kantakouzenos, his wife the empress Eirene and their daughter Helena. This means that on this ceremonial occasion, the imperial women shared space with their husbands. There was no separate coronation banquet for them and their gynaikonitis.

Yet, there is also evidence that female members of the imperial court spent time with each other socially and ceremonially, separate from the male members of the court. For example, in the early 1300s, Maria, Michael IX's wife, lived in Thessalonike with her two daughters, Anna and Theodora, while her son Andronikos (and most likely also Manuel) grew up with his grandfather in Constantinople. For that reason, when in 1327 Andronikos III received his sister Theodora in Didymoteichon, Gregoras claims that Andronikos had 'never seen her'. ${ }^{27}$ We also have evidence that there was a gender division in the Kantakouzenos family. In 1346, the female members of the household were given the imperial tent by way of women's quarter upon the marriage of one daughter, Theodora, with Orhan, outside of Constantinople, while the emperor stayed with army officials and confidants. ${ }^{28}$ Later, when Kantakouzenos' daughter, now married, came to Constantinople for a short visit, we are told explicitly that she 'stayed with her mother and sisters for three days' before going back to her husband. ${ }^{29}$

That female members of the court grew up separate from male counterparts is perhaps best exemplified by the existence of a sort of kindergarten for imperial daughters but also for 'young girls of exceptional beauty, not only of good origin but also of lower background, to be reared in the imperial palace like imperial daughters, and, as need arose, to be betrothed to the satraps of the Mongols'. ${ }^{30}$ This remark of Kantakouzenos

25 Gregoras, History, I, 564.10-22.

26 Gregoras, History, II, 788.10-15.

27 Gregoras, History, I, 391.14-16. Van Dieten suggests that Andronikos III's claim never to have seen his sister is an overstatement: van Dieten, Nikephoros Gregoras. Rhomäische Geschichte, II, 1, 193-194.

28 Kantakouzenos, History, II, 587.24-588.1.

29 Kantakouzenos, History, III, 28.21-22.

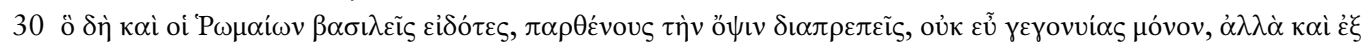

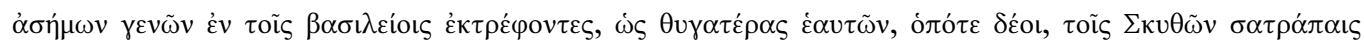

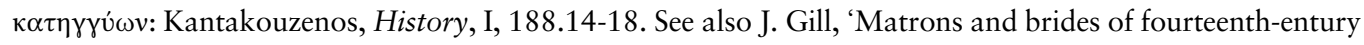
Byzantium,' Byzantinische Forschungen 9 (1985) 39-56, 48. 
refers to practices during the reign of Michael VIII and Andronikos II, who married their illegitimate daughters to the Mongol rulers. It seems likely that the girls mentioned by Kantakouzenos were raised together in the women's quarters of the palace. What the palace 'kindergarten' for girls consisted of remains unclear. Presumably its main purpose was to familiarise princesses and other young girls with life at court and to prepare the girls for marriage alliances.

There are more examples of a special bond between the empress and her female family members. Pachymeres says that it was the empress Theodora (and not Michael VIII) who prepared a retinue for her daughter Anna in 1269, before her marriage to the heir of the Serbian throne. Theodora specifically requested of the negotiators that they investigate the circumstances under which her daughter would have to live in Serbia. ${ }^{31}$ Pachymeres also mentions the fondness of Andronikos II's wife the empress Eirene for her only surviving daughter Simonis; she is described as being very dear to the emperor, but 'even dearer to her mother'. ${ }^{32}$ After Simonis' marriage to the Serbian $\mathrm{kral}$ in 1299 , which took place when the princess was only five years old, the empress Eirene visited her daughter in Thessalonike (in 1303) 'for the affection for her daughter pressed her hard so that by coming [to Thessalonike] she would be able to see her and embrace her'. ${ }^{33}$

It was not only imperial women who spent time with each other separate from the male court. On certain occasions the wives of the court officials were actively involved in ceremonial related to the court of women. In contrast to the early Byzantine period, there were no particular, separate female court dignities any longer by the early Palaiologan period, like the zoste patrikia, but there were still sebastokratorissai, kaisarissai and other women who were granted their husband's title. They were supposed to be present at the reception of an imperial fiancée when she arrived from abroad and were to dress her in red, befitting an empress, explains the fourteenth-century ceremony book known as Pseudo-Kodinos. ${ }^{34}$ This ceremony is expressed visually in some of the miniatures of the Epithalamion in Vaticanus graecus 1851, written for the arrival of an imperial bride. ${ }^{35}$ There is also evidence that the wives of officials were received in audience by the empress, just as her husband received the officials. Pachymeres says that during the feast of the

31 Pachymeres, History, II, 453.1-26.

32 Pachymeres, History, III, 303.18-19. See also Pachymeres, History, IV, 323.20-21.

33 Pachymeres, History, IV, 415.2-3.

34 This is the only passage in the ceremony book which mentions these female titles. See R. Macrides, J. A. Munitiz and D. Angelov, Pseudo-Kodinos, The Constantinopolitan Court Offices and Ceremonies (Farnham and Burlington, VT 2013) 266.19-268.2.

35 If we accept Cecil Hennessy's mid-fourteenth century date for the manuscript, the depiction of the arrival of the imperial bride may actually reflect Pseudo-Kodinos' ceremony. However, the proposed date has not been accepted by most scholars, who consider a Komnenian date more plausible. See C. Hennessy, 'A child bride and her representation in the Vatican Epithalamion, Cod. Gr. 1851,' Byzantine and Modern Greek Studies 30.2 (2006) 115-150 and C. Hilsdale, 'Constructing a Byzantine augusta: a Greek book for a French bride,' The Art Bulletin 87.3 (2005) 458-83. 
Apostles (29 June 1292), the emperor Andronikos II received 'grand men' (megistanoi) while his wife the empress Eirene received their wives (matronoi) in audience:

For, when this feast was celebrated and reception meetings of the grand men with the emperor and the ladies with the empress had to take place, while a great number of grand ladies presented themselves, the old lady of good descent Strategopoulina arrived, a niece of emperor John Doukas and married to Constantine Strategopoulos, who was later blinded by the son of that emperor [Theodore II Laskaris]. Because it was not yet time for her to appear before the empress, she was seated somewhere outside, waiting for an invitation. But then the wife of the porphyrogennetos was brought in, with befitting splendor and luxury, and with a grand escort and following. She approached her aunt or rather her grandmother (for her grandmother on her father's side was the cousin of that woman [Strategopoulina] who herself was in fact a daughter of the brother of the emperor, who had been given the title of sebastokrator, and her grandmother descended from a second brother and was married to the protovestiarites Alexios Rhaoul). ${ }^{36}$ Although the old lady was supposed to give her seat to the one who approached, who had the second rank after the empress, she looked down upon her granddaughter, because of her old age and because she considered her just a child, and she did not even rise up, appealing to her by pointing to her age and her weakness. Eirene, then, felt immediately offended and could not withhold her anger: she, a daughterin-law of the emperor and wife of a man placed above the despots, while the other [Strategopoulina] had not received any of the honours reserved for someone related to the emperor, was considered an ordinary person because her husband, while still alive, had never received any title. She then turned her anger into sorrow and dedicated herself with tears and lamentations to an exaggerated complaint.What had happened did not escape her husband [Constantine porphyrogennetos]. He then, being also proud himself, his reasoning disturbed by the lamentations of his wife, held it right to vex the old lady in return for the insolence brought upon his wife by her. ${ }^{37}$

The reason why Pachymeres reports this episode is to demonstrate the direct cause of the emperor's conflict with his brother and the subsequent downfall of the latter. However, the passage is also relevant for a study of the women's court. It shows that the empress received female dignitaries in audience and that these women were somehow supposed to keep to a ranking system, just as their husbands; the grand ladies who were received by the empress had to wait before they were called forward in a particular order. There seem to have been seats available for them 'outside', most likely before the

36 For an explanation of the complicated family relations, see Failler, Pachymeres, History, III, 172 note 29. The point is to show the high status of Eirene Rhaoulina, who surpassed Strategopoulina in rank.

37 Pachymeres, History, III, 173.2-175.4. 
room where the empress received the dignitaries' wives. As far as the separation between men and women is concerned, this passage does not specify if the reception ceremony of the grand ladies happened in the same space, such as a triklinos (ie. of the palace at Nymphaion, because the court was staying there at that time), for example, as occurred during the reception of the male title holders. Yet, it appears that the male and female courts were to a certain extent ceremonially separate.

\section{The empress' reliance on eunuch servants}

Throughout Byzantine history, eunuchs served emperors and empresses alike, creating a sphere of imperial segregation. Recent research has shown that eunuchs were still an integral part of the imperial household in late Byzantium, albeit a small one. ${ }^{38}$ Late Byzantine sources particularly underline the ceremonial role of eunuch servants who attended imperial women. Indeed, a ceremonial connection between imperial females and eunuchs is suggested by Pseudo-Kodinos. In the chapter on the coronation of an emperor, Pseudo-Kodinos states that at a certain moment during the ceremony, 'the new empress stands up and, supported from both sides by either two relatives of the closest kind or, if she does not have relatives, by two eunuchs, descends the steps and takes her place before the solea'. ${ }^{39}$

This is the only passage in Pseudo-Kodinos to mention eunuchs. The text may refer to the coronation of Anna of Savoy by her husband Andronikos III, in $1327 .{ }^{40}$ As an empress of foreign origin, Anna had certainly no 'relatives of the closest kind' to support her.

Princesses were also among those commonly accompanied by eunuchs. Imperial eunuchs are mentioned as a part of the therapeia, retinue, of princess Anna Palaiologina, composed by the empress Theodora for Anna's marriage to the second son of the Serbian king in $1269 .{ }^{41}$ Likewise, eunuchs were present at the marriage of Theodora, the daughter of John Kantakouzenos, who by 1346 had crowned himself emperor. ${ }^{42}$ In that year Theodora was given in marriage to Orhan, in Selymbria, and during a prokypsis ceremony (a glorification ceremony in which curtains would be drawn in order to show the bride standing on a platform) kneeling eunuchs held torches around her. ${ }^{43}$

38 N. Gaul, 'Eunuchs in the late Byzantine empire,' in Eunuchs in Antiquity and Beyond, ed. S. Tougher, (Swansea 2002) 199-219. For Byzantine eunuchs in general, see K. M. Ringrose, 'Living in the shadows: eunuchs and gender in Byzantium,' in G. Herdt (ed), Third Sex, Third Gender. Beyond Sexual Dimorphism in Culture and History (New York 1996) 85-109 ; S. Tougher, The Eunuch in Byzantine History and Society (Abingdon and New York 2008).

39 Pseudo-Kodinos, 224.4-7.

40 Gaul, 'Eunuchs,' 204.

41 Pachymeres, History, 453.1-26.

42 Although Kantakouzenos had proclaimed himself emperor, he had not yet moved into the imperial palace in Constantinople. As Niels Gaul points out, this raises some questions about where eunuchs were employed. Were eunuchs still serving in aristocratic households or only in the imperial court? How had Kantakouzenos acquired these eunuchs? See Gaul, 'Eunuchs,' 205.

43 Kantakouzenos, History, II, 588.1-16). 
Other evidence of eunuchs as special servants for the empress's household comes from the life of St. John of Herakleia, which was written by the saint's nephew Nikephoros Gregoras. As Niels Gaul points out, John was one of very few eunuchs originating from a higher social background. ${ }^{44}$ As the result of a childhood illness he became a castrate, after which it was decided

on the less arduous way for the child, so that since he would, after all, be henceforth no good passing his life at home, he might be of use for the women's quarters of the imperial palace. ${ }^{45}$

Becoming a eunuch is associated here with a future of service in the empress's household. Indeed, John of Herakleia entered the court of the Nicaean emperor where he served in the empress's household and became a novice of the empress's spiritual father. ${ }^{46}$

Also, in the thirteenth- or fourteenth-century romance Kallimachos and Chrysorroi, eunuchs are associated with the female ruler. They are supposed to behave as protectors and guards but are portrayed as deceitful and secretly plotting against their mistress. They are called 'evil', ${ }^{47}$ 'treacherous', ${ }^{48}$ as well as 'trusty ${ }^{49}$ and 'faithful guards ${ }^{, 50}$ and are described as behaving ceremonially when they enter a room: 'they entered, did obeisance and immediately left according to their custom and rank'. ${ }^{51}$ They secretly tell the king of the empress's behaviour, but to her 'those sons of vipers, treacherously showed boundless humility and much submission'. ${ }^{52}$ These citations reveal that the early Palaiologan audience of the romance considered it normal that eunuchs were the guards and protectors of (imperial) female rulers, and acted as mediators and messengers, but at the same time it was acceptable to despise them for their characteristics.

44 Although we know little about the origin of Palaiologan eunuchs, Niels Gaul suggests that the existing evidence does not point to many eunuchs originating from well-attested families: Gaul, 'Eunuchs,' 200.

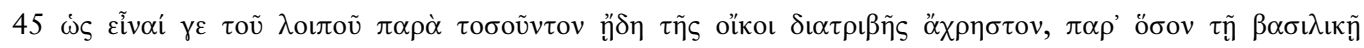

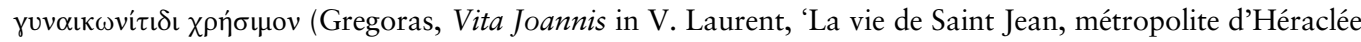
du Pont' Archeion Pontou 6 (1934) 29-63, 34.9-11. The translation is by Gaul, 'Eunuchs,' 202. For John of Heraclea see also F. Halkin ed., Bibliotheca hagiographica graeca, 3rd ed., 3 vols., Subsidia Hagiographica 8a (Brussels 1957) no. 2188, 34.

46 Gaul, 'Eunuchs,' 204.

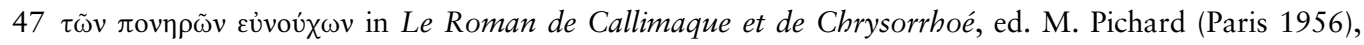
2199.

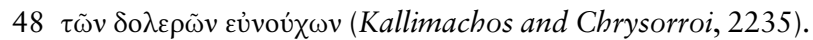

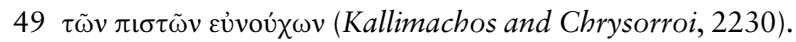

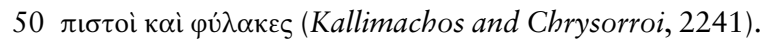

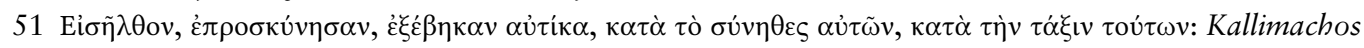
and Chrysorroi, 2226-2227 trans. G. Betts, Three Medieval Greek Romances. Velthandros and Chrysandza, Kallimachos and Chrysorroi, Livistros and Rodamni (New York and London 1995) 80.

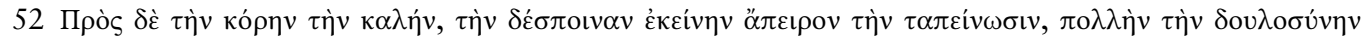

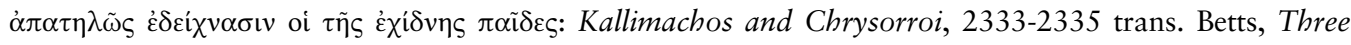
Medieval Greek Romances, 82. 
The eunuch in the romance Livistros and Rodamni is also attendant upon the empress and clearly acts for her as a go-between. For the hero of the story, Livistros, it is easier to reach his beloved empress through 'her extremely handsome eunuch who was the lady's confidant in her talk, her secrets and her hidden counsels' ${ }^{53}$ Indeed, the eunuch, whose name is Vetanos, plays a mediating role between the lovers, either dispatching messages or persuading his lady to answer. Also here we encounter stereotypes: 'the whole race of eunuchs loves flattery, especially when they are involved in an affair of love'. ${ }^{54}$ The intermediating eunuch is receiving many gifts: 'how I dispatched him and with what presents would make a long tale and I cannot tell it. In any task every intermediary willingly receives a gift and then does what is required'. ${ }^{55}$ It is clear that access to the princess is to be arranged through her eunuch servant, who received gifts for his services.

That imperial women in late Byzantine romances were accessible via eunuchs probably had its origins in reality. Kantakouzenos associated eunuchs in particular with the empress Anna of Savoy, whose supporters 'and many other eunuchs, who had great influence on the government' shared in the wealth of Kantakouzenos' mother, after having caused the old lady's death. ${ }^{56}$ This discrediting passage points not only to the existence of eunuchs, but also to the influential role of domestic staff in the empress Anna's government. As noted earlier in the passage about Alexios Apokaukos' attempt at bribery, the importance of domestic servants in Anna's government is also mentioned by the historian Gregoras. ${ }^{57}$ Similar to the eunuch in the romance Livistros and Rodamni, Anna of Savoy's domestics were given gifts in order to appease the empress. One could argue that both historians willingly portray Anna's government as weak in saying that it was relying on domestics and eunuchs 'whose influence went far beyond the empress's privy chambers'. ${ }^{58}$ Even though Kantakouzenos had good reason to write negatively about Anna - she was his adversary in the second civil war - he and Gregoras are eager to employ gender stereotypes to discredit the empress. That Kantakouzenos and Gregoras perceive the empress Anna's government rather negatively as relying on eunuchs,

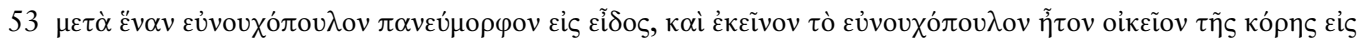

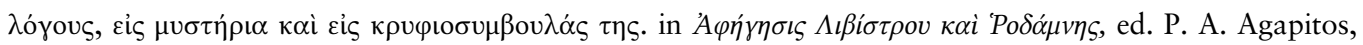

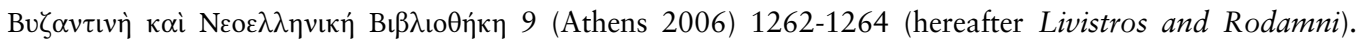
Trans. Betts, Three Medieval Greek Romances, 119-120.

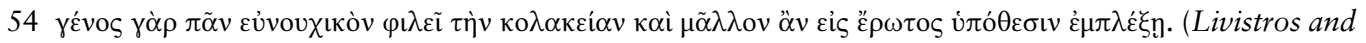
Rodamni, 2233-2234). Trans. Betts, Three Medieval Greek Romances, 139.

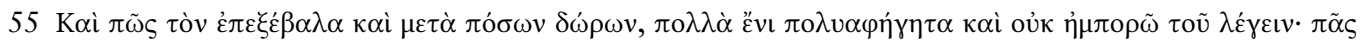

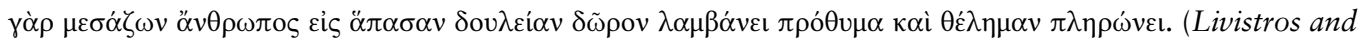
Rodamni, 2252-2255). Trans. Betts, Three Medieval Greek Romances, 140.

56 Kantakouzenos, History, II, 223.22-23. For a translation of the entire passage, see Gaul, 'Eunuchs,' 204205.

57 Gregoras, History, II, 711.6-9.

58 Gaul, 'Eunuchs,' 205. 
corresponds with Kathryn Ringrose's observations on the negative portrayal of the empress's reliance on eunuchs by ninth- and tenth-century historians. ${ }^{59}$ One might, therefore, conclude that a similar role could be attributed to the small group of eunuchs in late Byzantine government.

The presence of eunuchs at court indicates a degree of imperial segregation (a special sphere around the emperor and empress) and also a need for, or at least, a ceremonial mediation between male and female spheres. Scholars have emphasised the importance of the mediating role of eunuchs in the early and middle Byzantine court. Kathryn Ringrose, for example, argues that in the ninth- and tenth-centuries, the Byzantine empress had a structural need for eunuchs as they gave her access to people outside of her imperial household. ${ }^{60}$ This mediating role of eunuchs at court lasted until the end of the Byzantine empire. Even as late as 1433, eunuchs were seen accompanying the empress Maria of Trebizond, when she attended the liturgy in the church of Hagia Sophia. ${ }^{61}$

\section{The empress' participation in politics and military campaigns}

Now that we have established that a separate gynaikonitis still existed and that the empress was attended by her own servants, in particular by eunuchs, we should question to what extent empresses by the thirteenth century shared in the activities of the emperor. The only other mention of a gynaikonitis in this context is by George Pachymeres, in relation to emperor Michael VIII Palaiologos (1259-1282). Pachymeres says that Michael VIII, before the re-conquest of Constantinople in 1261, was joined by the Seljuq sultan Izz al-Din Kaykaus II (1246-1257) and his entire household, including women and children. Shortly before, the sultan and his retinue had fled Konya. Michael VIII welcomed the sultan, but thought it not a good idea to take his gynaikonitis (consisting of the sultan's mother, several wives and children and their attendants) with him on campaign:

the emperor sent those around him [the sultan], and especially the women and children, to Nicaea for safekeeping, seemingly in order to secure their safety, so that those without defense would not be harmed. For it did not seem a good idea that those people, inexperienced and deriving from the gynaikonitis, should march out together with the emperor. ${ }^{62}$

As Pachymeres implies, Michael VIII thought it undesirable to take the sultan's gynaikonitis on military campaign for the women and children would not be able to protect themselves in case of danger. Whether Michael VIII made an exception for the sake of the security of

59 K. M. Ringrose, 'Women and power at the Byzantine court,' in A. Walthall (ed), Servants of the Dynasty: Palace Women in World History (Berkeley and Los Angeles 2008) 77.

60 Ringrose, 'Women and power at the Byzantine court,' 65-81, 74-77.

61 This is mentioned by Bertrandon de la Broquière, Voyage d'Outremer, ed. Ch. Schefer (Paris 1892) 156157. See also É. Malamut, 'L'impératrice byzantine et la cour (XIIIe-XVe siècle),' 645-661, 657.

62 Pachymeres, History, I, 185.12-16. 


\section{Frouke Schrijver}

the sultan's gynaikonitis, or whether it was also considered unusual for the empress and her gynaikonitis to follow the emperor on his expeditions, is not directly addressed. These were tumultuous years and the emperor was often on the move. Yet, there is no evidence that Michael VIII's wife Theodora ever accompanied her husband on expeditions, travels or campaigns either before or after they had moved into the Blachernai palace in Constantinople. On the contrary, we know that Theodora did not intend to leave the palace when she learned of her husband's plans to go on campaign in 1282. Instead, she asked Michael VIII to remain in Constantinople in 1282, but he ignored her plea and went on campaign together with his 'sons and male relatives', ${ }^{63}$ despite his old age and weak health, after which he died close to Rhaidestos. From Pachymeres' narrative of the campaign and the emperor's death it becomes clear that Theodora was not with him when he died. ${ }^{64}$ The empress seems to have remained in the palace on this occasion.

The extent to which empresses actively accompanied their husbands on military campaigns and stayed in military camps is linked to broader questions about their involvement with the emperor in terms of shared space or political affairs. An interesting case in this respect may be Anna of Hungary, the first wife of the emperor Andronikos II Palaiologos (1282-1328). In 1280, some time before Michael VIII died, Andronikos II had been sent on campaign by his father with the aim of fighting off the Turks, who had just captured the regions of the Meander: 'He [Andronikos II] then took off with the empress to restore the situation there, accompanied by, among others, a great number of grand men.....65 The campaign was not very successful and Andronikos waited in Nymphaion for the right moment to return to the capital. ${ }^{66}$ Although it is not specified where Anna stayed during the expedition, we may assume that she resided in the palace in Nymphaion. She was left in Anatolia when Andronikos II returned to Constantinople: 'in the same year emperor Andronikos returned from Anatolia, having left the empress there', most likely in Nymphaion. ${ }^{67}$ Several months later, during Andronikos II's absence in June 1281, the young empress died. Her body was taken to Nicaea and was buried there. ${ }^{68}$ Although Pachymeres makes clear that Anna went to Anatolia with Andronikos II, nothing is said about her actually following her husband onto the battlefield. It is plausible that she stayed in Nymphaion, where there was an imperial palace. Unfortunately, we are not informed about the residence of her children, nor whether she gave birth to her second son in Nymphaion (she had two sons with Andronikos II: Michael, born in 1277, and Constantine, born around 1280), nor whether a

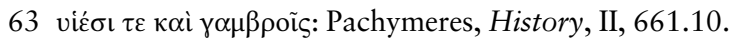

64 Pachymeres, History, II, 659-663. See also: A.-M. Talbot, 'Empress Theodora Palaiologina, wife of Michael VIII,' Dumbarton Oaks Papers 46 (1992) 295-303, 297.

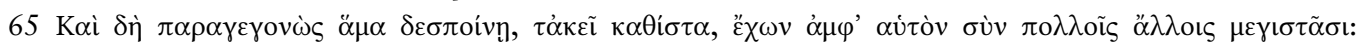
Pachymeres, History, II, 593.6-7.

66 Pachymeres, History, II, 599.15-16.

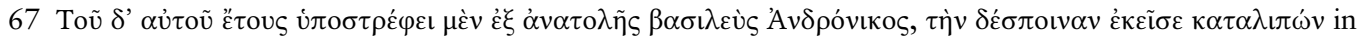
Pachymeres, History, II, 627.14-15.

68 On her death and funeral arrangements in Nicaea: Pachymeres, History, II, 629.18-633.11. 
gynaikonitis had accompanied her to Anatolia. However, it seems unlikely that she would have stayed in Nymphaion for about a year without support from servants.

When Andronikos II became the sole emperor of Byzantium, he married Yolanda (Eirene) of Montferrat. There is no evidence of mixed gender events at court, nor of the empress joining her husband on campaign. In fact, after 1280 Andronikos II did not go on campaign at all, but instead left the campaigning to his sons, relatives and generals. He did move the entire court occasionally to different locations. We know that Eirene was present with her husband in Nymphaion, when the emperor held court there around $1292 .{ }^{69}$ In 1299 , they left together for Thessalonike, in order to bid farewell to their sole daughter Simonis, who was about to marry the Serbian ruler Stephan Milutin (1282-1321). On that occasion, the emperor took with him nearly all the residents of the imperial palace, says Pachymeres. ${ }^{70}$ The situation changed in 1303, when Eirene started to live separately from her husband and held her own court in Thessalonike. ${ }^{71}$ From that moment onwards, we can assume that there was an imperial gynaikonitis in Thessalonike, which transformed itself into a court in its own right. The empress issued decrees, received visits from monks and aristocratic ladies. ${ }^{72}$ The mention of 'paidopoula of the empress', possibly servants, in a document from the region of Serres can also be connected to Eirene's court in Thessalonike. ${ }^{73}$ The court in Thessalonike also served Maria, the wife of Michael IX, and their daughters Anna (born in October 1295) and Theodora (born in June/July 1296), while the son and heir Andronikos (and most likely his brother Manuel) stayed with his grandfather in the palace in Constantinople. ${ }^{74}$ We know that the co-emperor Michael IX often went on campaign, but there is no evidence of Maria accompanying him. It seems likely that from ca. 1305 there were no female members of the imperial family living permanently in Constantinople and that the separation between a male court (that of the emperor Andronikos II) and a female court (that of Eirene of Montferrat) had become rather absolute.

Evidence of gender segregation between imperial women and men of Andronikos III's court in the violent 1320s is hard to establish. We know that Kantakouzenos persuaded Andronikos III (1328-1341) to leave his young wife Eirene in Constantinople at the start of the first civil war, when Andronikos III and his supporters had to flee Constantinople in 1321. Kantakouzenos' accounts give two core explanations for this action. Firstly, their

69 Pachymeres, History, III, 173.2-4.

70 Pachymeres, History, IV, 307.1-13. Gregoras suggests that empress-mother Theodora stayed behind. Andronikos II took his brother Constantine, who was imprisoned in the palace at that time, with him in a cage, for fear of giving his mother a chance to free him when the emperor was away. See Gregoras, History, I, 203.22-24. See also Talbot, 'Empress Theodora,' 298.

71 D. M. Nicol, The Byzantine Lady: Ten Portraits (Cambridge 1994) 52-57.

72 Gregoras says that she discussed with them the shortcomings of her husband. See Gregoras, History, I, 235.19-236.13.

73 L. Bénou (ed),, Le codex B du Monastère Saint-Jean-Prodrome (Serrès). A (XIIIe-XVe siècles) (Paris 1998) 212.

74 This can be deduced from a passage in Gregoras, who says that the emperor Andronikos III had never seen his sister until she visited him in the 1330s: Gregoras, History, I, 391.14-16. See above, 000. 
flight would be dangerous and they would not be able to protect their wives until they held a city or stronghold; secondly, women would slow them down, and Eirene would not be able to follow the men quickly because of her pregnancy. ${ }^{75}$ Later in the same year, however, she joined him in Adrianople, after Andronikos III had sent ships to bring her from Constantinople. ${ }^{76}$ After a couple of months, the imperial couple moved their base to Didymoteichon. From there, Andronikos III went on military campaign again, leaving his wife and the city in the capable hands of the mother of Kantakouzenos. ${ }^{77}$ Eirene did not follow Andronikos III after he and the old emperor had temporarily made peace in Constantinople in 1322. Instead, Andronikos III returned to Didymoteichon where she was still staying. ${ }^{78}$ In 1324, while she was ill, Andronikos III sent her to Constantinople, where he intended to join her later, but she died in Rhaidestos in Thrace. Thus, although Kantakouzenos' history indicates that Eirene followed her husband, it would be misleading to see this as evidence of a lack of gender segregation. The 1320s were a period of war and Andronikos III's court, de facto a counter-court, was itinerant during this time. Moreover, there is no evidence that Eirene accompanied her husband during his military activities.

In 1326 Andronikos III married Anna of Savoy in Constantinople, but soon after the wedding celebrations the couple left for Didymoteichon. According to Kantakouzenos, the empress rather informally intermingled with the emperor and Kantakouzenos, implying that her activities were not exclusively confined to the women's quarters. ${ }^{79}$ The imperial family stayed for a long time in Didymoteichon, where, in 1330, Andronikos III became gravely ill. A description of his near-death shows that Anna, pregnant at that time, was present at Andronikos III's deathbed, holding hands with him in front of all the officials, while the emperor gave an emotional speech. ${ }^{80}$ This and other passages point to informality in the emperor's manners and a lack of strict gender rules in certain social contexts, although it is unclear to what extent Kantakouzenos' characterisation is a representation of events that serves his own ends. Nevertheless, if there was a relaxation of gender rules at the court of Andronikos III, this did not result in the inclusion of imperial women in the military domain. There is no evidence that the empress shared in the frequent military activities of her husband, either during the itinerant years of the court, or when the household resided in Constantinople. ${ }^{81}$ Later, after the death of

75 Kantakouzenos, History, I, 52.13-53.21.

76 Kantakouzenos, History, I, 119.8-11.

77 Kantakouzenos, History, I, 125.14-17.

78 Kantakouzenos, History, I, 169.8-11.

79 Kantakouzenos, History, I, 369.10-370.9.

80 Kantakouzenos, History, I, 392.21-393.1.

81 Andronikos III's household resided in Constantinople between 1334 and 1339. During the last years of the reign of Andronikos III, the court was itinerant again and empress Anna moved with her husband from stronghold to stronghold. Gregoras says that in 1339 the imperial family was in Adrianople (Gregoras, History, I, 546.16-17), but in 1339/40 they resided in Thessalonike for a short time, while the emperor went on expeditions (Gregoras, History, I, 550.9-10). In the spring of 1341 'the emperor left Thessalonike with wife and children and entered after twelve days a city, which is called Didymoteichon. He stayed there many days and came to Constantinople at the end of spring. (Gregoras, History, I, 554.8-10). 
Andronikos III in 1341, Kantakouzenos and Gregoras emphasise the influence of the gynaikonitis of the empress Anna and claim that her life was shaped by servants in the palace in Constantinople, as discussed above. It remains unclear whether her gynaikonitis was equally important to her when her husband was still alive.

With regard to Kantakouzenos' household, from his own History we get the impression that his wife was the ideal Byzantine woman; humble, reliable, supportive of her husband, stepping in when necessary and even taking up a political role in times of distress, but in fact generally more concerned with the affairs of her children and the household. Like Andronikos III, Kantakouzenos was often on campaign and frequently lived separate from his wife. On one occasion, Kantakouzenos tells his wife that he is leaving her and her gynaikonitis at home, under the pretence that it was too much trouble to take them with him from their house in Gallipoli, where the Kantakouzenos family resided in the early $1320 \mathrm{~s} .{ }^{82}$ In fact, he left for Constantinople to meet secretly a political opponent. This makes clear that Kantakouzenos had no intention of sharing political secrets with his wife. We do not get the impression that Eirene Kantakouzene followed her husband on any of his campaigns. When in 1341 Kantakouzenos had been proclaimed emperor by his supporters and the second civil war set in, his household was based in Didymoteichon. Kantakouzenos and two of his sons left their residence to defend or win over strongholds in Thrace, while his youngest son was with his mother in Constantinople and Eirene was left in Didymoteichon with her three daughters. She led the defense of the city until Kantakouzenos returned in 1343. We know nothing of her gynaikonitis during this period, while, as I have shown above, during the same period, the gynaikonitis of the empress Anna was considered influential.

\section{Conclusion}

Although the evidence is not abundant, there seems to have been a division in the Palaiologan imperial household based on gender. Imperial women and their gynaikonitis were not supposed to partake in certain typical imperial male activities and their lives remained largely separate from their husbands'. Although they were not confined to the palace and sometimes resided in locations other than Constantinople - as in the example of the itinerant wives of Andronikos III - there is no evidence that the empresses joined their husbands on the battlefield and openly shared in military and political decision-making. There was joint feasting, but the court still retained a female ceremonial sphere where the empress met the wives of office holders according to protocol. Social interaction between the male and female court was common, but a social sphere around the empress, consisting of her attendants and daughters, still existed. Some evidence points at a (perhaps limited) spatial separation between men and women at court during everyday life.

82 Kantakouzenos, History, I, 24.24-25. 


\section{Frouke Schrijver}

An important objective, still, of imperial women in the palace was to bear children, take care of them in the imperial household, with the help of a gynaikonitis, and play their segregated part in ceremonies, sometimes with the help of eunuch servants. And yet, despite all these elements of segregation, empresses were also able to influence their husbands or to yield power on their own account. Gender segregation in the imperial household should, therefore, not be mistaken for a lack of female influence on the political life of the empire. 